\title{
TIETEEN TULEVAISUUDET
}

Tiedettä on arvosteltu siitä, että se on monopolisoinut totuuden. Onko esimodernissa ybteiskunnassa vallinnut uskonnon ja valtion ykseys korvautunut modernissa yhteiskunnassa tieteen ja valtion liitolla? Onko tämä yhdistelmä luonut asiantuntijavallan ja onko tieteen valtiollisesti turvattu asema estämässä ja tukahduttamassa muita tietomuotoja?

Tuottaako tiede enemmän paboinvointia kuin byvinvointia?

Ilkka Pirttilän pobdiskeluissa tarkastellaan neljäa vaibtoehtoista tieteen tulevaisuudenkuvaa. Niiden sijasta bän pitää mabdollisena kokonaan uutta kulttuurityyppiä ja sitä vastaavaa tiedetyyppiä. 'Tulevaisuuden luovat ennen kaikkea kaikki ibmiskunnan ibmiset konkreettisilla ratkaisuillaan ja teoillaan', kirjoittaja toteaa.

\section{Skenaariot}

Tulevaisuuden tutkimuksessa käytetään erilaisia ajattelumetodeja. Skenaariomenetelmä on synteettinen perusmenetelmä. Siinä luodaan vapaamuotoisesti tulevaisuuden kehitysmahdollisuuksia.

Esitän neljä tieteen tulevaisuutta koskevaa mallia. Ne perustuvat siihen, että oletan tieteen olevan sisäisesti sidoksissa koko yhteiskuntaan ja kulttuuriin. Tieteen logiikka määräytyy yhteiskunnallisesti; tieteen tulevaisuus perustuu koko yhteiskunnan tulevaisuuteen.

Ensimmäisessä skenaariossa oletan 'teknoutopioiden" toteutuvan. Tämä tuottaa "dualistisen tieteen' eli tieteen, joka on jakautunut yhtäällä teknotieteeseen ja toisaalla humanistiseen teoriaan hyvästä elämästä.
Toisessa mahdollisuudessa ennakoin "teknologisen järjen" ylivallan voimistumista koko kulttuurissa ja sitä kautta myös tieteessä. Kehittyy kvantifioiva, toimintavälineitä hiova "insinööritiede".

Kolmas mahdollisuus on postmodernin kulttuurin täydellinen läpimurto. Kaikki yhteiskunnalliset instituutiot postmodernisoituvat: kehkeytyy 'postmoderni tiede".

Viimeisin olettamani malli merkitsee tieteen loppua. Tämä on tuloksena prosessissa, jossa työn automatisointi kehittyy niin pitkälle, että vaativa tietotyökin (tutkimustyö) voidaan siirtää koneille tai tieteen loppu on seurausta siitä antirationalistisesta liikkeestä, joka lakkauttaa tieteen ihmiskunnalle haitallisena ilmiönä.

\section{Teknoutopia ja dualistinen tiede}

Teknoutopia tarkoittaa utopiaa, joka muotoutuu tekniikan ansiosta. Tekniikka merkitsee kaikkia niitä välineitä ja menetelmiä, joita ihminen toiminnassaan (tavoitteiden aikaansaamisessa) tarvitsee. Utopia on yhtä kuin yhteiskunnallinen ihannetila.

Kirjallisuudessa on esitetty useita uuden tietoteknologian varaan rakentuvia utopioita. Näitä ovat tuottaneet André Gorz ("duaaliyhteiskunta"), Yonedi Masuda ("'informaatioyhteiskunta") ja muun muassa Alwin Toffler ('kolmannen aallon yhteiskunta").

Mikä yhdistää näitä kolmea visiota? Ensinnäkin ne kaikki uskovat tekniikan voimaan. Kirjoittajat ovat teknologisia deterministejä; tekniikan oletetaan luovan perustavat edellytykset uudelle yhteiskunnalle. Tekniikan ytimen he tulkitsevat informaatioteknologiaksi. Nuo visiot ovat aitoja utopioita; tulevaisuus tulkitaan nykyisyyttä paremmaksi. Masudan (1981) mukaan uuden teknologian ansiosta uusi kulttuurin kukoistus koittaa koko ihmiskunnalle. 
Tofflerin (1980) uusi kolmannen aallon yhteiskunta poistaa teollisen yhteiskunnan kivuliaat ongelmat (mm. ympäristöongelmat ja keskittymisen): Gorzilla (1980) duaaliyhteiskunnassa " vapauden valtakunta" kasvaa "välttämättömyyden valtakunnan" kustannuksella.

Käsiteltäviä utopioita värittää dualismi: yhtäällä ovat tekniikan mahdollisuudet ja pakot ja toisaalla ihmisten valinnat ja arvot.

Millainen on uuden yhteiskunnan tiede? Millainen on modernin teknologian mahdollistama tiede?

Masuda ja Toffler korostavat rationaalisuuden (järjen) kaksijakoisuutta: dualistisuutta. Yhtäällä on välineitä tuottava teknologinen tiede ja toisaalla arvoperusteinen eettinen teoria.

Miten tämä järjen dualismi konkreettisesti ilmenee?

Tofflerin mukaan uuden yhteiskunnan teollisuuden ytimenä ovat elektroniikka- ja tietokoneteollisuus, avaruusteollisuus, merien "'hyödyntämisteollisuus" ja biologinen teollisuus. Masudan ajattelussa tiede kulminoituu tietokoneeseen; uusi tiede on (puoliksi) yhtä kuin tietokone. Tämä tiede luo tarpeiden tyydytyksessä tarvittavat aineelliset hyödykkeet.

Kuitenkin sekä Tofflerin että Masudan tulkinnoissa "'henki määrää ainetta". Molempien mukaan rationaalisesti (tieteellisesti) perustellut arvot ohjaavat kulttuurin kehitystä. Masudalla uudet arvot määräytyvät tieteeseen (teologiaan ja etiikkaan) turvautuen. Tofflerin ajattelussa uuden yhteiskunnan pioneerit "'teknokapinalliset" ovat arvorationaaleja tieteellisiä asiantuntijoita; he vaativat, että sovellettavan tieteen ja tekniikan tulee palvella rationaalisesti asetettuja arvoja.

Gorzin eksplikoinnit tieteen tehtävästä uuden yhteiskunnan luomisessa ovat vähäiset. Gorz näyttää olettavan, että teknologinen tiede toimii ja edistyy. Tämä on välttämätöntä, jotta työaikaa voidaan radikaalisti vähentää. Gorz korostaa teknisiä sovellutuksia tuottavan tieteen merkitystä utopiansa toteutumisessa. Gorz puhuu kulttuurisesta ja eettisestä muutoksesta, joka avautuu duaaliyhteiskunnan myötä. Se luo mahdollisuuden joukkojen laajamittaiseen osallistumiseen kulttuurin luomisessa. Tämä edellyttää tietoverkkojen ja laboratorioiden avoimuutta kaikelle kansalle.

\section{Insinööritiede ja teknologisen järjen ylivallan kulttuuri}

Henryk Skolimowski (1984, 11) kirjoittaa

\begin{abstract}
"Uudella ajalla kehittyi nykyisin vallitseva asenne, jota edustaa klassinen positivismi ja 1900-luvun looginen empirismi. Arvot erotetaan tiedosta. Katsotaan, etteivät arvot edusta tietoa ja tieto nostetaan arvojen yläpuolelle. Tieto on ytimeltä̈n fyysisiä asioita koskevaa jäsennystä. (...) asenne on luonut arvotyhjiön yhteiskuntaamme, yliopistoibimme ja yksityiseen elämäämme."
\end{abstract}

Max Horkheimer (1977, 6-19) on kuvannut järjen historiallista kehitystä samansuuntaisesti kuin edellä. Horkheimerin mukaan aiemmin ideat osoittivat ihmisille päämäärät. Ne olivat järjen ydin. Moderni ja valistus julisti tuollaisen järjen taikauskoksi. Järjestä tuli väline, instrumentti. Kun järki oli "vanhalla ajalla" objektiivinen, se ilmaisi maailman konstituution ja antoi perustelun korkeimmasta hyvästä ja ihmisen tehtävästä maailmassa. Valistuksen myötä järki formalisoitui ja subjektivoitui. Ainoa hyväksyttävä tapa käsittää, mitä järki on, oli nyt käsittää se ihmisen kalkylointikyvyksi. Yksilön tuli laskea todennäköisyyksiä voidakseen valita oikeat keinot annetun päämäärän saavuttamiseksi. Päämäärästä sinänsä ei subjektiivinen järki osannut sanoa mitään.

Välineellinen järki on formalisoivaa ja kvantifioivaa. Adorno ja Horkheimer (1979) ovat kuvanneet "'valistuksen dialetiikkaa". Valistuksesta nykyaikaan kulkeva kehityslinja on muuttanut ihmisten ajattelutapaa ja tiedettä. Kun klassisessa ajattelussa oletettiin, että maailmaa hallitsevat sisäiset voimat ja kätketyt kvaliteetit, nïn uusi ajattelutapa korvasi käsitteet kaavoilla, syyt säännöillä ja motiivin todennäköisyydellä. "'Tietäminen" sai uuden sisällön; ihminen "tietää" kohteensa siinä määrin, kuin se on hänen kontrolloitavissa.

Formaalinen logiikka näytti tien kalkyloivaan maailmaan. Maailma käsitettiin formaalisten kaavojen kautta. Uusi logiikka oli ekvivalenssin logiikkaa: erilainen tehtiï yhteismitalliseksi. Erot asioiden välillä katosivat; tilalle tulivat numerot. Todellisuus tulkittiin samanlaatuiseksi ja täten todellisuutta koskevaa tieteellistä ajattelua voi olla vain yhtä laatua. Ero luonnontieteiden ja ihmistieteiden välillä oli tarpeeton.

Mikäli tämä suunnitelma toteutuu, tieteestä tulee puhdas insinööritiede. Se kehittää välineitä, mutta ei problematisoi toiminnan päämääriä.

Skolimowski (1984) on puhunut ''bazarovismista' (Turgenjevin romaanista 'Isät ja lapset') maailmankatsomuksena. Katsomuksen perustana on usko ja halu jatkuvaan taloudelliseen kasvuun, ohjeelliseksi ajattelutavaksi korotettu kustannus-hyöty -analyysi ja yritykset operationaalistaa kaikki ihmiselä- 
män puolet. Bazarovismi on hänen mukaansa tätä nykyä yleinen katsomustapa, joka on tunkeutunut kaikkialle ja erityisesti tieteeseen ja korkeimman koulutuksen rakenteeseen.

Onko tulevaisuuden tiede bazarovilainen insinööritiede?

\section{Postmoderni kulttuuri ja dekonstruoitu tiede}

Jean-Francois Lyotard (1985, 7-9) on määrittänyt postmodernin tilanteeksi, jossa "'suuret kertomukset" katoavat. Suurilla kertomuksilla hän tarkoittaa tulkintoja, jotka tarjoavat kognitiivis-eettisen selityksen maailmasta ja ihmisestä. Lyotard katsoo, että suurten kertomusten katoamisen logiikka ilmenee erityisesti tiedon "'metakertomusten" tasolla eli tieto- ja tiedekäsitysten suhteen.

Lyotard (emt., 51-60) arvostelee ensinnäkin " valistuksen virittämää kansanvalistusajattelua" ja "'humboltilaista sivistysyliopistoa" sellaisina tiedon metakertomuksina, jotka eivät enää toimi. Tiedettä ei voi enää perustella kansan parhaalla ja tiedon itseisarvolla. Lyotardin mukaan tiedon subjektin kautta legitimoituva tiede on postmodernissa tilanteessa mahdoton. Tiedettä ei perustella tieteestä itsestään käsin, vaan legitimointi on siirtynyt tieteen ulkopuolelle, markkinoille (emt., 66-84).

Teoksessaan 'Le Differend" 'Lyotard puhuu postmodernin tiedon tavasta "leikkiä rajoilla". Se paremminkin "pukeutuu rajoihin kuin riisuu rajoja". Postmoderni tiede ei usko absoluuttiseen totuuteen: tieto ei absoluuttisella tavalla paljasta totuutta, siirrä tuntemattoman ja tunnetun rajaa. Tiede merkitsee leikittelyä tiedetyn ja tiedettävän rajamailla.

Jacques Derrida on luonnehtinut ydinkäsitettään suomennetussa teoksessaan Positioita (1988) eri tavoin. Derridalle tutkimus ("filosofia") merkitsee tekstuaalista työtä. Hän (1988, 64-65) kirjoittaa:

\footnotetext{
"'(..) on kehitettävä tekstuaalisen työn strategiaa, joka hetki hetkeltä lainaa vanhan sanan filosofiasta ja tuottaa heti uuden vanhasta eroavan (...). Täten tekstuaalinen työ ei voi olla puhtaasti 'teoreettista', 'käsitteellistä'tai 'diskursiivista', ts. se ei voi olla diskurssia, jota olemus, merkitys totuus, ideaalisuus jne. kokonaisuudessaan säätelevät. Tekstiksi kutsumani myös käytännöllisesti kirjoittaa uudelleen ja muuttaa kuvatun kaltaisen diskurssin rajat."
}

Derridalainen dekontruktio merkitsee tieteessä olemassaolevan tutkimustradition uutta "marginaaleissa ja rivien väleissä" tapahtuvaa tulkintaa. Leikitään rajoilla: hyväksytään ja hylätään olemassaolevia käsitteitä ja teorioita. Kuitenkin tiede pysyy tieteenä; osiin purettuna mutta uudelleen ja uudenlaisena kokoonpantuna.

Postmoderni tiede ylittää tieteen ulkoiset rajat (tiede kontra metafysiikka, tiede kontra taide, tiede kontra journalismi jne.). Mahdollisiksi käyvät esimerkiksi raportit, joissa kokeellisen tutkimuksen asetelma ja vaikkapa runot vuorottelevat tai muuten ignoroivat. Leikit tieteen sisäisillä rajoilla (sosiologia kontra psykologia, historia kontra sosiologia jne.) voimistuvat. Tästä on elävänä esimerkkinä Michel Foucault'n laaja tuotanto, jossa on yhdistetty sosiologiaa, valtio-oppia, historiaa ja filosofiaa.

Tulkinta, jossa tiede nähdään rajoilla leikkimisenä ja tekstuaalisena työnä, olettaa tieteen olevan ihmisten luoma konstruktio. Baudrillardin (1983) mukaan kyseessä on "simulacrumin" (merkitysjärjestelmien objektivoinnin) uusi vaihe.

Baudrillard (1983) esittää, että modernissa vaiheessa voidaan vielä tehdä ero merkkien ja todellisuuden välille. Merkeillä on referenttinsä niiden ulkopuolisessa todellisuudessa ja täten todellisuutta voidaan kuvata merkeillä, jotka ovat siitä riippumattomia. Tiede voi olla kuva (siitä riippumattomasta) todellisuudesta. Uudessa simulacrumin vaiheessa eli "simulaatiossa" tuo ei enää päde; todellisuus on kadonnut. Merkkejä ja niiden referenttejä ei voi erottaa toisistaan; merkit viittaavat aina itseensä. Tiede ei voi luoda kuvaa siitä riippumattomaksi oletetusta todellisuudesta. Tieteellinen tutkimus on itsereflektiota; esimerkiksi jokainen psykologinen tutkimus on aina analyysi psykologian tieteentraditiosta.

Ilmeistä on, ettei tuollainen tieteen logiikan muutos ole vain seuraamusta siirtymisestä simulacrumin (ja koko kulttuurin) uuteen vaiheeseen. Tiede on myös osaltaan luonut uutta totaalisesti merkittyä todellisuutta, jossa tieteen on pakko purkaa ja koota itse itsensä.

\section{Tieteen loppu}

Jälkiteollisessa yhteiskunnassa työ jakaantuu ensinnäkin teolliseen työhön, palvelutyöhön ja tietotyöhön. Nämä voidaan vielä puolittaa suorittavaan ja innovoivaan tasoon.

Nykyään ainakin suorittava teollinen työ ja suorittava tietotyö voidaan (ainakin periaatteessa) automatisoida. Miten käyt tutkimustyölle innovoivana tietotyönä?

1970-luvulla syntyi kognitiotiede, joka analysoi tiedon käsittelyä. Se lähti liikkeelle filosofiasta, logiikasta, kielitieteestä, psykologiasta ja kybernetii- 
kasta ja kiteytyi vähitellen itsenäiseksi kognitiotieteelliseksi tutkimusalueeksi.

Kognitiotieteen ydinprobleemana on oppivien koneiden, tekoälyn ja asiantuntijajärjestelmien tutkimus. On pohdittu sitä, voivatko "oppivat koneet"' oppia tekemään tutkimustyötä ja onko "tekoäly" tieteellisesti riittävän älykäs. On myös arvioitu mahdollisuutta korvata tieteelliset asiantuntijat formaalisilla asiantuntijajärjestelmillä.

Millainen on tulevaisuus? Antti Hautamäki (1988, 157-158) katsoo, että tätä nykyä (vuonna 1988) tutkimus oli jakaantunut kahtaalle. Ensinnäkin tutkittiin ihmisten älykästä tietopohjaista ongelmanratkaisua (esikuvana tutkija) ja toiseksi tutkittiin ihmisen monimutkaisia oppivia järjestelmiä (esikuvana kehittyvä lapsi). Tulevaisuudessa näiden suuntausten oletetaan yhtyvän ja silloin keinotekoiset tietojärjestelmät tukeutuisivat koko inhimilliseen kulttuuriin oppien ja luoden uutta; kyettäisiin jäljittelemään taiteilijan työtä (tulkittuna tutkijan työn ja lapsen oppimisen synteesiksi).

Tieteen ansiosta ollaan lähellä sitä tilannetta, jossa tieteen teko, ainakin periaatteessa, voidaan siirtää tietokoneille. Katoaako tutkimustyö ja tutkijan ammatti esimerkiksi vuoteen 2020 mennessä?

Max Scheler (1980) piti filosofisia ja sosiologisissa kirjoituksissaan tiedettä keskeisenä ihmisen vieraantumisen aikaansaajana. Vieraantumisen ydin on objektiivisen metodin olettamuksessa, jonka mukaan tutkija ja tutkimuskohde erotetaan loogisesti toisistaan. Erottelun tuloksena syntyy käsitys todellisuudesta (luonnosta), jonka kanssa tutkimus ja tutkija ei ole sisäisessä ja persoonallisessa suhteessa. Tiede vieraannuttaa ihmisen todellisuudesta.

Tiedettä on arvosteltu siitä, että se on monopolisoinut totuuden. Paul Feyerabendin (1978) mukaan esimodernissa yhteiskunnassa vallitsi uskonnon ja valtion ykseys ja modernissa yhteiskunnassa vallitsee tieteen ja valtion liitto. Jälkimmäisestä on päästävä eroon ensinnäkin siksi, että se luo asiantuntijavaltaa ja toiseksi siksi, että tieteen valtiollisesti turvattu asema estää ja tukahduttaa muita tietomuotoja (metafysiikkaa, kosmologiaa ja myyttistä spekulaatiota).

Tiedettä on syytetty myös siitä, että se on tuottanut enemmän pahoinvointia kuin hyvinvointia. Ensinnäkin tieteeseen tukeutuva suurteollisuus on tuhonnut ympäristöämme. Toiseksi tiede on luonut "'tuhoteknologian", modernit joukkotuhoaseet. Kolmanneksi esimerkiksi lääketieteen on esitetty luoneen enemmän sairautta $(\mathrm{mm}$. lääkkeiden sivuvaikutukset) ja koulun enemmän oppimattomuutta kuin oppineisuutta. Tieteen avulla on tuotettu enemmän kyvyttömyyttä (asiantuntemattomuutta) kuin kyvykkyyttä (asiantuntevuutta).
Ollaan sitä mieltä, että tiede tulee hävittää. Skolimowskin mukaan tämä ei merkitse askelta taaksepäin vaan edistystä. Hän $(1984,25)$ kirjoittaa:

\begin{abstract}
"'Tieteellisen järjen iltahämärä, jota nyt olemme todistamassa ei ole välttämättä ibmisyyden iltabämärä. Tieteellisen järjen on kallistuttava loppuunsa ja päästettävä meidät musertavista lonkeroistaan; vain näin me voimme korjata tiedon ja arvojen välisen jännittyneen subteen."
\end{abstract}

\section{Tiede vuonna 2020}

Edellä esitetyt neljä skenaariota voivat loogisesti toteutua kolmella tavoin. Ensinnäkin tilanne lähitulevaisuudessa (esimerkiksi vuonna 2020) voi olla sellainen, että jokin neljästä mahdollisuudesta on todella toteutunut; esimerkiksi koko tiede on muuttunut mittaavaksi insinööritieteeksi. Toiseksi voi esiintyä kahden tai kolmen mahdollisuuden kombinaatioita; esimerkiksi yhtäällä insinööritiede ja toisaalla postmoderni spekulaatio. Kolmanneksi ne kaikki voivat realisoitua rinta rinnan; esimerkiksi on "kovan sektorin" mittaavaa insinööritiedettä (siirrettynä puoliksi tietokoneille) ja on "pehmeän sektorin" postmodernia teoriaa.

Toki on mahdollista, ettei mikään näistä neljästä vaihtoehdosta toteudu, vaan kehittyy kokonaan uusi kulttuurityyppi ja sitä vastaava tiedetyyppi (esimerkiksi jälkimodernin jälkeinen kulttuuri ja jälkimodernin tieteen jälkeinen tiede).

Itse tulevaisuuden tutkimus ei ole tulevaisuuden ydintekijä, vaan tulevaisuuden luovat ennen kaikkea ihmiskunnan ihmiset konkreettisilla ratkaisuillaan ja teoillaan. Me ja he (syntymättömät) luovat tulevaisuuden tieteen.

\section{LÄHTEET}

Adorno, T \& Horkheimer, M. 1947. Eclipse of Reason. New York.

Baudbrillard, J. 1983. Simulations. New York.

Derrida, J. 1988. Positioita. Helsinki.

Feyerabend, P. 1972b. Science in a Free Society.London.

Hautamäki, A. 1988. Tekoäly, logiikka ja tiedon esittäminen teoksessa Kognitiotiede (toim. A. Hautamäki). Helsinki.

Horkheimer, M. 1977. Eclipse of Reason. New York.

Gorz, A. 1980. Adieux au Prolétariat. Paris.

Lyotard, F. 1983. The Differend. London.

Lyotard, F. 1985. Tieto postmodernissa yhteiskunnassa. Jyväskylä.

Masuda, Y. 1981. The Information Society as Post-industrial Society. Bethesda.

Skolimowski, H. 1984. Ekofilosofia. Vaasa.

Toffler, A. 1980. The third Wave. London. 